\title{
Spatial and temporal variation of the benthic macrofauna in a grossly polluted estuary from southwestern Spain
}

\author{
J. E. Sánchez-Moyano • I. García-Asencio • \\ J. C. García-Gómez
}

Received: 16 April 2009/Revised: 30 September 2009/Accepted: 3 October 2009/Published online: 27 October 2009

(C) Springer-Verlag and AWI 2009

\begin{abstract}
The spatial-temporal variation of subtidal macrofauna communities of the Odiel-Tinto estuary, one of the most polluted areas in the world, was studied along a sampling period of 4 years (and 3 sampling events). This system has shown typical water and sediment characteristics of estuarine areas although the inner stations showed high concentrations of heavy metals. The structure of the macrofauna community was associated with granulometry, the percentage of organic matter and the heavy metals. Like in other estuaries, the community was dominated by polychaetes (especially by small size opportunistic taxa), meanwhile the crustaceans were the least abundant. Some changes during the sampling period were slight increment in richness and diversity; greater presence of molluscs and crustaceans in the inner zones; a more homogeneous spatial distribution of opportunistic taxa and a higher number of taxa involved in the differences among the estuary areas. The period of study does not allow assuring that these changes have been due to a true improvement or to natural cycles of the communities in naturally stressed systems. So that it would be necessary the establishment of a long-term monitoring programme to study the evolution of the macrofauna communities to state whether the corrective measures could achieve an improvement of this environment. This programme should focus on the study of macrobenthic community's structure and on those selected parameters,
\end{abstract}

Communicated by L. Gimenez.

J. E. Sánchez-Moyano ( $ه)$ · I. García-Asencio .

J. C. García-Gómez

Dpto. Fisiología y Zoología, Facultad de Biología,

Universidad Sevilla, Avd. Reina Mercedes 6,

41012 Sevilla, Spain

e-mail: smoyano@us.es which have been the major structuring factors for these communities.

Keywords Heavy metal - Odiel estuary - Tinto River . Macrofauna $\cdot$ Recovery $\cdot$ Southwestern Spain

\section{Introduction}

The Tinto-Odiel estuary (SW Spain) is one of the most polluted areas in the world, with extremely high concentrations of heavy metals in the sediments (Nelson and Lamothe 1993; Ruiz 2001; Sainz and Ruiz 2006) and very acidic waters ( $\mathrm{pH} 2-4$; Elbaz-Poulichet et al. 2001). Both rivers flow through the Iberian Pyrite Belt, one of the most important mining areas in western Europe, which have been worked since the Phoenician and Roman times. The estuarine zone includes an area of salt marsh and, since the 1960 s, a heavily industrialised urban area. This industrial activity includes phosphate fertilizer plants, oil refinery, power plants and other chemical industries. Furthermore, in this area exists an important port activity that has supposed the construction of a long breakwater, causing an interruption of the littoral sedimentary fluxes, and the periodic dredging of the bottom. However, it is one of the more important wetlands for migrating birds from southern Europe together to the nearby Doñana National Park. This zone was declared as a biosphere reserve by UNESCO's MAB Programme in 1983, Natural Protected Area in 1989 by Andalusia Government, and is a RAMSAR site and a Special Zone for Birds Protection in the European Union.

To minimize the industrial impact on this system, between 1986 and 1998, the Environmental Agency of the Government of Andalusia established the Odiel and Tinto River Correction Plan (Usero et al. 2000). Since then, the 
evolution of the estuary has been studied from the chemical point of view, in relation to the origin, variation and nature of the heavy metals (Elbaz-Poulichet et al. 2001; Ruiz 2001; Bermejo et al. 2003; Sainz and Ruiz 2006; among others). There are some works related to distribution and migrations of birds (e.g., Sanchez et al. 2006) and ecophysiology of salt-marsh macrophytes (e.g., Nieva et al. 2001), but there are few studies related to the contamination effects on organisms, except some on Ostracoda and Foraminifera (Ruiz et al. 2004; Ruiz et al. 2008), and ecotoxicology (Luque et al. 1999; Morillo et al. 2005). On subtidal soft-bottom macrofauna, there is only one investigation previous to the implementation of the Correction Plan (Cano and García 1987) and a sampling survey enclosed in a general study of the Gulf of Cadiz communities (Drake et al. 1999).

The soft-bottom macrofauna is one of the key components of the food web of estuaries and is considered a key element of many marine and estuarine monitoring programmes (Ysebaert and Herman 2002). An extensive literature has described the relationships between the benthic estuarine community and the effect of contaminants (e.g., Pearson and Rosenberg 1978; Warwick and Clarke 1993; Dauvin 2008). However, estuaries are stressful environments due to the interaction of local physical, geological, chemical and biological factors (Saiz-Salinas and GonzálezOreja 2000; Dauvin et al. 2006) and, as a consequence, the estuarine macrofauna communities exhibit high resistance to pollution (Boesch and Rosenberg 1981). This often makes difficult in the interpretation of the effects of disturbance on the animal communities and confounds the impacts of anthropogenic activity on estuarine biotic integrity (Rakocinski et al. 1997; Dauvin et al. 2006; Dauvin 2008).

The temporal scale of sampling is a key issue for monitoring programmes in the coastal zone (Comín et al. 2004). Many authors argue that the temporal variability of environmental parameters remains high, but the changes in the community can be undetected, so that the structure of the communities remains stable for long periods of time (Govaere et al. 1980; Livingston 1987; Turner et al. 1995). Some aspects on environmental disturbance can be identified only if there are sufficient data to show long-term trends, which are not usually comparables with short-time scale fluctuations. Without a long-term perspective, natural variations in community structure could be mistakenly attributed to anthropogenic disturbance (Thrush et al. 1994; de Paz et al. 2008).

The main aim of the present study was to contribute to the evaluation of the environmental quality of the OdielTinto system in function of the spatial-temporal variation of subtidal macrofauna communities. This work spanned a sampling period of 4 years (and 3 sampling events) although our future research objective will be to establish a long-term monitoring programme of the soft-bottom macrofauna that allows us to see if the corrective measures established since 1986 have resulted in remarkable improvement of this environment.

\section{Materials and methods}

The Odiel and Tinto Rivers have 128 and $92 \mathrm{~km}$ in length, a drainage basin area around 2,300 and $1,680 \mathrm{~km}^{2}$ and an average annual water discharge of 405 and $160 \mathrm{Hm}^{3}$, respectively. To the west of the Huelva city, the Odiel River is a well mixed estuary and is divided in numerous channels and islands. The Tinto River also makes up a less extensive mixed estuary to the east of Huelva before the rivers confluence in the Padre Santo Channel. This channel is directed toward south-east along $13 \mathrm{~km}$ until the mouth, in the Atlantic Ocean.

Sampling was undertaken during ebb tide in the summer of 1998, 2000 and 2002 at 8 subtidal stations: 3 in Odiel River, 1 in Tinto River and 4 in Padre Santo Channel (Fig. 1). The criterion of this spatial design was covering all the subtidal environments of the study area. At each station, six replicates samples (five for biological analysis and one for sediment analysis) were taken with a $0.05 \mathrm{~m}^{2}$ van Veen grab. Each replicate was sieved in seawater through a mesh of $0.5 \mathrm{~mm}$, fixed with $4 \%$ formalin and stained with Bengal rose. Macrofauna was sorted and, whenever possible, identified to family level. Identification of animals to taxonomic levels equal to or even higher than family has been used in many benthic studies (Herman and Heip 1988; Warwick and Clarke 1991; Vanderklift et al. 1996; PagolaCarte et al. 2001) and has been found to be sufficient to determine changes in the composition of the soft-bottom benthic macrofauna (Sánchez-Moyano et al. 2006).

For sediment analysis, granulometry was assessed following the Boyoucos method (Boyoucos 1934), and organic matter percentage was obtained as weight loss by ignition at $450^{\circ} \mathrm{C}$ for $24 \mathrm{~h}$ (mean value of 3 replicates per station). The other sediment parameters were measured by laboratories of the Environmental Agency of the government of Andalusia (South Spain): total organic carbon (TOC) was determined by EPA 415.1; fats and hydrocarbons were measured by extraction and FT-IR spectrophotometry; total nitrogen in the sediment was assessed via Kjedahl digestion; phosphate was measured using UV visible spectrophotometry; and the metal contents were measured by SM $3111 \mathrm{~A}$ and $\mathrm{B}$ for $\mathrm{Cd}, \mathrm{Zn}, \mathrm{Cu}$ and $\mathrm{Cr}$, and EPA 245.1 for $\mathrm{Hg}$. The index of geoaccumulation $\left(I_{\text {geo }}\right)$ has been used as a relative measure of metal pollution in the sediments for $\mathrm{Cr}, \mathrm{Cu}$ and $\mathrm{Zn}$ according to the regional background established by Ruiz (2001) for unpolluted sandy and silty-clayey sediments. 


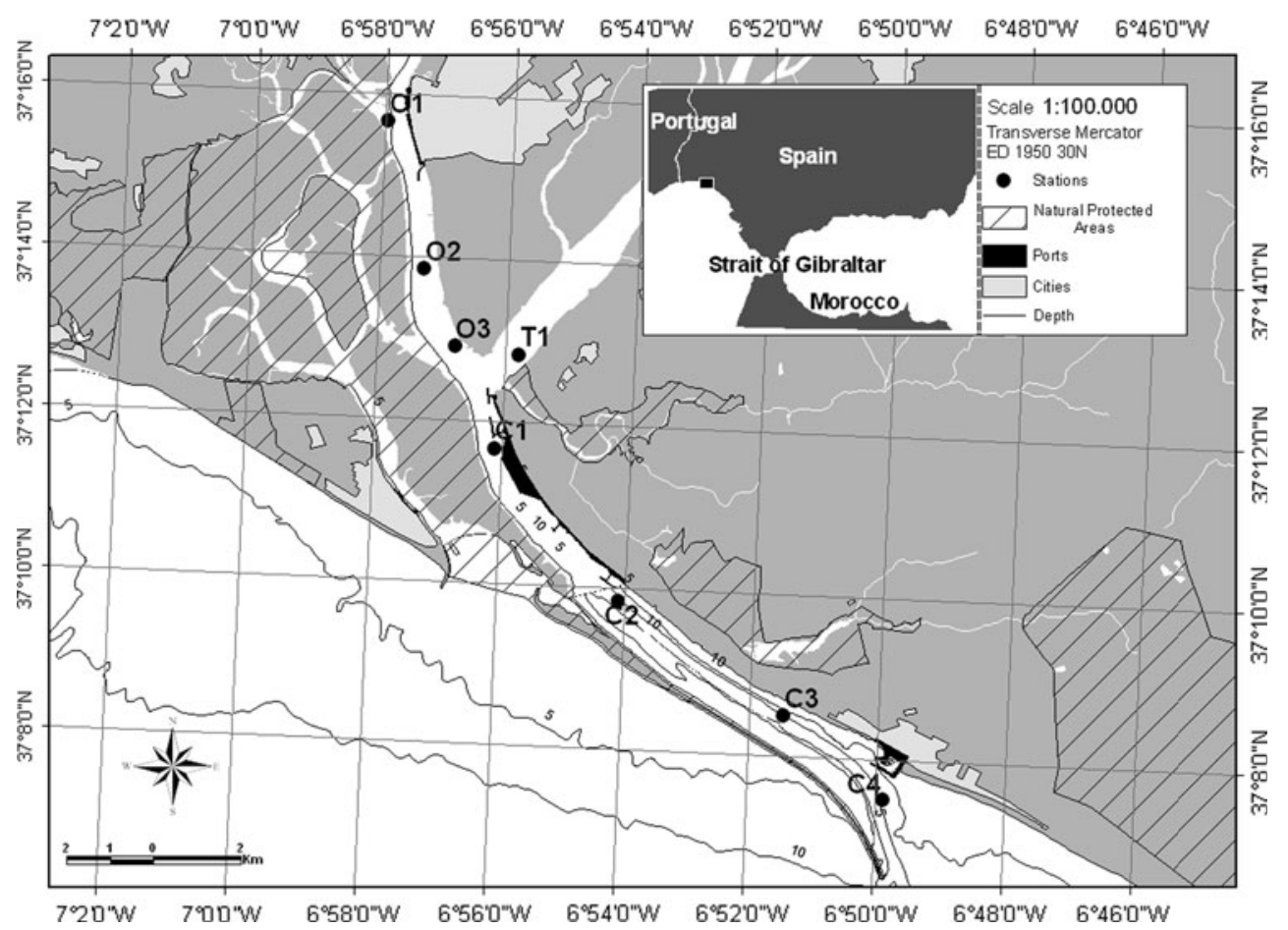

Fig. 1 The Odiel-Tinto estuary and location of the sampling stations

$I_{\text {geo }}=\log _{2}\left(C_{n} / 1.5 \times B_{n}\right)$, where $C_{n}$ is the value of the element $n$, and $B_{n}$ is the background data of that element. Following Ruiz (2001), the index values were divided into five groups: unpolluted $\left(I_{\text {geo }}<1\right)$; very low polluted $\left(1<I_{\text {geo }}<2\right)$; low polluted $\left(2<I_{\text {geo }}<3\right)$; moderate polluted $\left(3<I_{\text {geo }}<4\right)$; highly polluted $\left(4<I_{\text {geo }}<5\right)$ and very highly polluted $\left(I_{\mathrm{geo}}>5\right)$.

For water analysis, a water sample per station was obtained close to the bottom by a vertical Alpha Van Dornstyle bottle. The following parameter was measured in situ: temperature, conductivity and salinity by conductivimeter WTW LF-323; pH by pH meter WTW 330i and dissolved oxygen by oximeter WTW OXI-196.

Univariate and multivariate analysis for environmental variables and macrofauna communities were performed using the PRIMER v 5.2.8 software package. Previously, the replicate data were pooled for the multivariate analysis. The macrofauna data were analysed to obtain the total number of taxa, abundance, evenness and Shannon diversity index using neperian logarithms. Spatio-temporal differences for univariate variables were analysed by a twoway ANOVA, after verifying normality (KolmogorovSmirnov test) and homogeneity of variances (Barlett test). The data were $\log _{10}(x+1)$ transformed prior to analysis. Homogenous groups were separated by a Student-Newman-Keuls (SNK) test set at the 5\% significance level. Temporal differences for environmental variables were analysed by one-way ANOVA.
Affinities between stations and/or samplings were established using MDS (non-metric multidimensional scaling) analysis with the taxa abundance (transformed by the fourth root). The validity of the ordination was verified with the Kruskal stress coefficient. The differences in community composition were tested with the non-parametric ANOSIM test (Clarke and Green 1988). Percentage of similarity analysis (SIMPER; Clarke 1993) was used to determine the taxa involved in grouping of the different stations and/or samplings. This analysis, based on the matrix of similarity in taxa abundance obtained from the Bray-Curtis index, calculates the contribution of each taxa to either the dissimilarity between groups of stations (discriminatory taxa) or the similarity within a group (typical taxa). Sediment and water variables (transformed by log $x+1$ ) were examined using principal components analysis (PCA).

The relationship between the physical environment and macrofauna assemblages was analysed by BIOENV and canonical correspondence analysis (CCA). BIOENV analysis consists of comparing, through the harmonic rank correlation coefficient of Spearman, the rank similarity matrix on species abundance and the rank similarity matrix obtained through Euclidean distances with the abiotic variables (Clarke and Ainsworth 1993). CCA is based on a unimodal response model that constrains the ordination axes to be linear combinations of the environmental variables that maximize the dispersion of sample or taxa scores 
(Ter Braak 1986, 1990). In the ordinations, stations were represented as points and statistically significant environmental variables (after a Monte-Carlo permutation procedure) as arrows.

\section{Results}

\section{Environmental variables}

Water and sediment characteristics are showed in Table 1. Water parameters showed the natural trend of estuarine systems, e.g., increase in $\mathrm{pH}$ and decrease in salinity from inner to outer points. Sediments were dominated by silt and clay $(<0.063 \mathrm{~mm})$ with the exception of the two nearest stations to the mouth (C3 and $\mathrm{C} 4)$. The values of organic matter in sediment showed a natural trend of decreasing from high estuary until the river mouth. Other parameters such as TOC and metal contents have showed a similar spatial pattern. In relation to metal contents, most of them have showed higher concentrations in the upstream stations, except $\mathrm{Cd}$ and $\mathrm{Cr}$, which have showed scarce spatial differences.

To test the differences between sampling events in sediment parameters, one-way ANOVA was used with the station values as replicates (Table 2). There was scarce temporal variation of the composition of the sediments in the entire study zone. However, phosphate values have showed a great increment during the last sampling year (e.g., station O3 with 20.3 and $174.5 \mathrm{ppm}$ in 1998 and 2002, respectively) while total nitrogen values have decreased in the same period (e.g., station O3 with 1,023 and $23.43 \mathrm{ppm}$ in 1998 and 2002, respectively).

In relation to the geoaccumulation index, the stations were classified as unpolluted or very low polluted for $\mathrm{Cr}$ $\left(I_{\text {geo }}<1\right.$ or $\left.1<I_{\text {geo }}<2\right)$. However, during the all study period, most of stations were highly or very highly polluted by $\mathrm{Zn}$, and very highly polluted by $\mathrm{Cu}$, except stations $\mathrm{C} 3$ and C4 in 1998 (unpolluted) and station C4 in 2002 (low polluted).

PCA analysis, based on all measured parameters (water and sediment) and all samplings, is plotted in Fig. 2. The first two principal axes retained $61.6 \%$ of the variance (eigenvalues 8.5 and 3.8, respectively). The first principal component discriminated the stations mainly based on a gradient of $\mathrm{pH}(0.32), \%$ of organic matter $(-0.29)$ and $\%$ of sand (0.30) and silt $(-0.31)$, as stated by the eigenvectors. This axis separated stations according to a natural gradient from estuarine to marine environments. The second axis was influenced by other sediment parameters such as fats (0.39), hydrocarbons (0.39) and copper (0.29).
Macrofauna community

A total of 86 taxa were found in the studied area belonging to Phyla Annelida (27), Arthropoda (27 crustacean taxa), Mollusca (23), Echinodermata (3), Chordata (2), Cnidaria (1), Platyhelminthes (1), Nemertea (1) and Phoronidea (1). Abundance for each station and sampling is presented in Table 6 in Appendix. Polychaetes were the dominant group in all stations and samplings, mainly the abundance of the Spionidae.

Spatial and seasonal variations of number of taxa, Shannon diversity index and Pielou's evenness are plotted in Fig. 3. These univariate parameters have showed a general pattern of increasing toward the channel mouth, except for abundance at upstream stations (O1 to T1) during 2000 sampling (by the contribution of the polychaetes Spionidae) and station O3 during 2002 (2,520 individuals $\mathrm{m}^{-2}$ of the molluscs Cardiidae). Taxa number and Shannon diversity have ranged at a wide interval (e.g., 2 and 46 families and 0.96 and 2.84 of diversity index at stations $\mathrm{O} 1$ and C4, respectively, during 2002 sampling). The spatio-temporal differences of these univariate parameters were tested by two-way ANOVAs (Table 3). According to the SNK test $(P<0.05)$, there were significant differences between outer stations (stations C3 and C4) and the rest by all the parameters except abundance (this parameter did not show a clear spatial or temporal trend). Besides, there was a pattern of increasing in diversity, evenness and taxa number since 1998-2002 samplings, mainly in the channel stations (C1 to $\mathrm{C} 4)$.

A global MDS analysis of macrofauna community shows, independently of sampling period, the presence of two groups of stations: channel mouth stations (C3 and C4) and the more upstream points (Fig. 4). The first group is represented by the stations with more influence of the marine areas, sandy sediments and lower contents in sediment parameters. Meanwhile, the second group is comprised by stations with silty sediment and higher contents in the most of sediment parameters. Furthermore, a temporal pattern can be observed in MDS ordination from 1998 to 2002 samplings (it is indicated as a vertical arrow in Fig. 4).

The spatial-temporal differences in community composition were tested using a two-way crossed ANOSIM test. The test for stations gave a value of the global $R=0.57$ (significance level of $0.1 \%$ ) so that there were spatial differences across all samplings. Nevertheless, the pairwise test showed no significant differences between stations $\mathrm{O} 2$ and $\mathrm{O} 3(R=0.23$, significance level $=3.5 \%)$ and between $\mathrm{T} 1$ and $\mathrm{C} 1 \quad(R=0.14$, significance level $=$ $6.6 \%)$. For samplings, there were also global differences $(R=0.65$, significance level $=0.1 \%)$, although $R$ values for pairwise test showed no significant differences between 1998 and 2000 samplings $(R=0.38)$. 


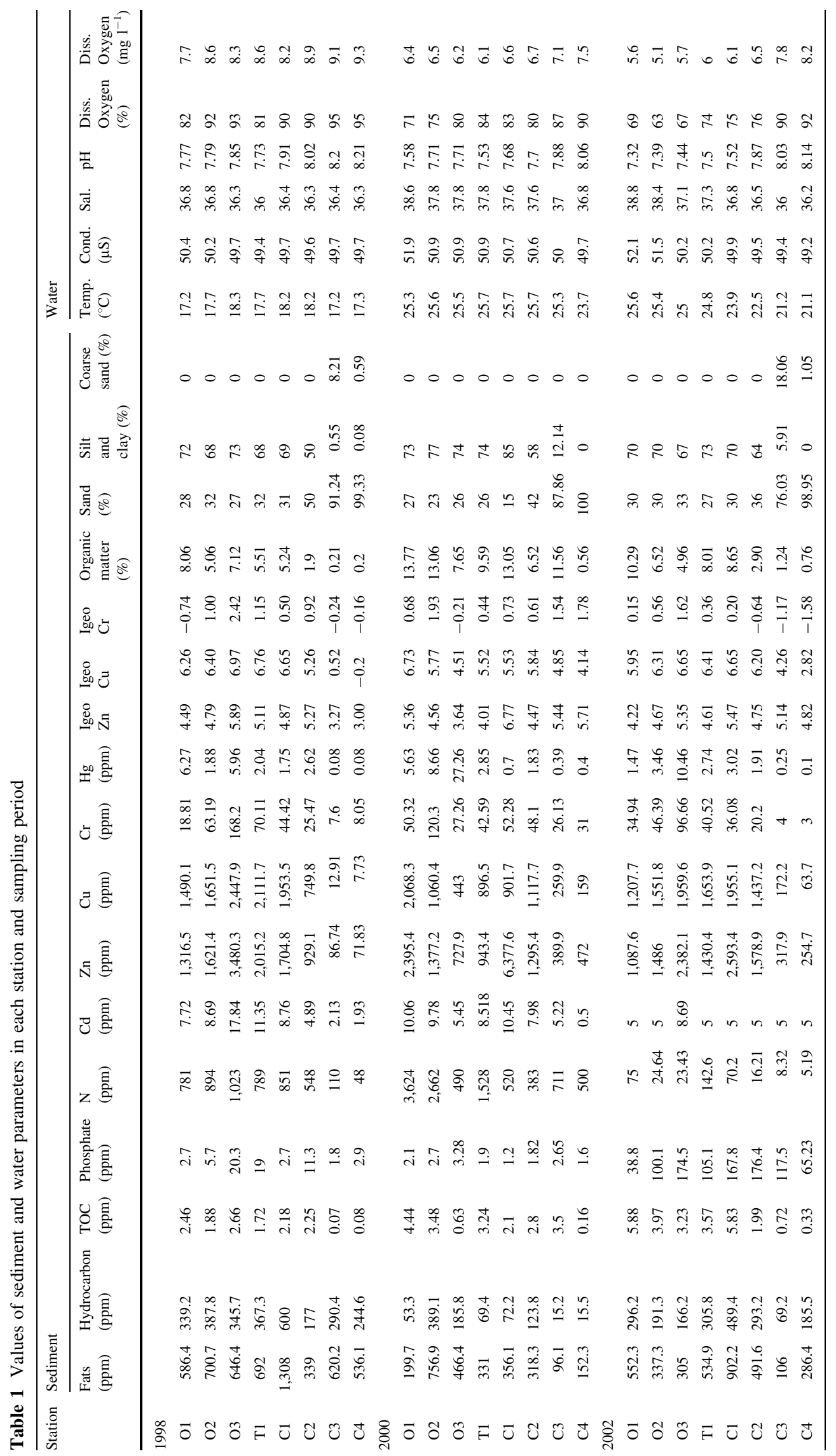


Table 2 Results of the one-way ANOVA for the temporal differences of sediment parameters

\begin{tabular}{|c|c|c|c|c|c|}
\hline Parameter & MS & MS error & $F$ & $P$ & $\begin{array}{l}\text { Homogeneous } \\
\text { group }\end{array}$ \\
\hline $\begin{array}{l}\text { Organic matter } \\
(\%)\end{array}$ & 0.24 & 0.11 & 2.19 & NS & - \\
\hline $\begin{array}{l}\text { Silt and clay } \\
(\%)\end{array}$ & 0.04 & 0.53 & 0.08 & NS & - \\
\hline TOC & 0.06 & 0.06 & 1.11 & NS & - \\
\hline $\mathrm{Cd}$ & 0.01 & 0.06 & 0.19 & NS & - \\
\hline $\mathrm{Zn}$ & 0.06 & 0.23 & 0.28 & NS & - \\
\hline $\mathrm{Cu}$ & 0.12 & 0.49 & 0.24 & NS & - \\
\hline $\mathrm{Cr}$ & 0.15 & 0.16 & 0.94 & NS & - \\
\hline $\mathrm{Hg}$ & 0.04 & 0.14 & 0.32 & NS & - \\
\hline Fats & 0.26 & 0.06 & 4.26 & $<0.03$ & $\underline{19982000} 2002$ \\
\hline Hydrocarbon & 0.94 & 0.11 & 8.87 & $<0.001$ & $\underline{19982002} 2000$ \\
\hline $\mathrm{N}$ & 5.02 & 0.20 & 24.78 & $<0.0001$ & $\underline{19982000} 2002$ \\
\hline Phosphate & 5.22 & 0.06 & 84.08 & $<0.0001$ & 199820002002 \\
\hline
\end{tabular}

The homogeneous groups according to the SNK test $(P<0.05)$ are indicated with a continuous line. Degrees of freedom $=2$

NS not significant

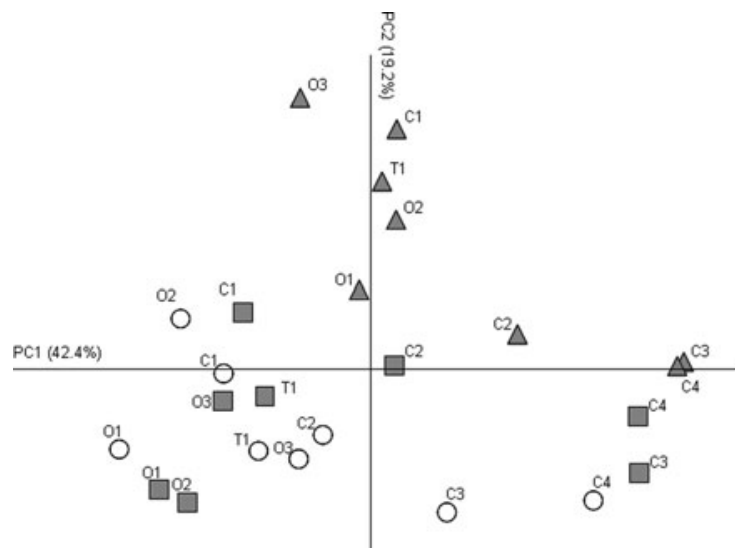

$\Delta 98$

Fig. 2 PCA analysis plot for all stations and sampling periods from parameters of water and sediment. The percentage of variability explained by the two principal axes is given

One-way ANOSIM tests for each sampling showed spatial differences at a significance level of $0.1 \%$ (1998: $R=0.40 ; 2000: R=0.45 ; 2002: R=0.66$ ). Homogeneous groups according to pairwise test are plotted in Fig. 5. At all samplings, the inner stations could be considered as a homogeneous group, meanwhile outer channel stations (C3 and $\mathrm{C} 4)$ showed significant differences with the rest.

The SIMPER analysis gave the best discriminating taxa between the groups of stations or sampling periods identified in the multivariate analyses. Table 4 gives the contributions of taxa to discriminate between inner and channel mouth stations. In 1998 sampling, the differences
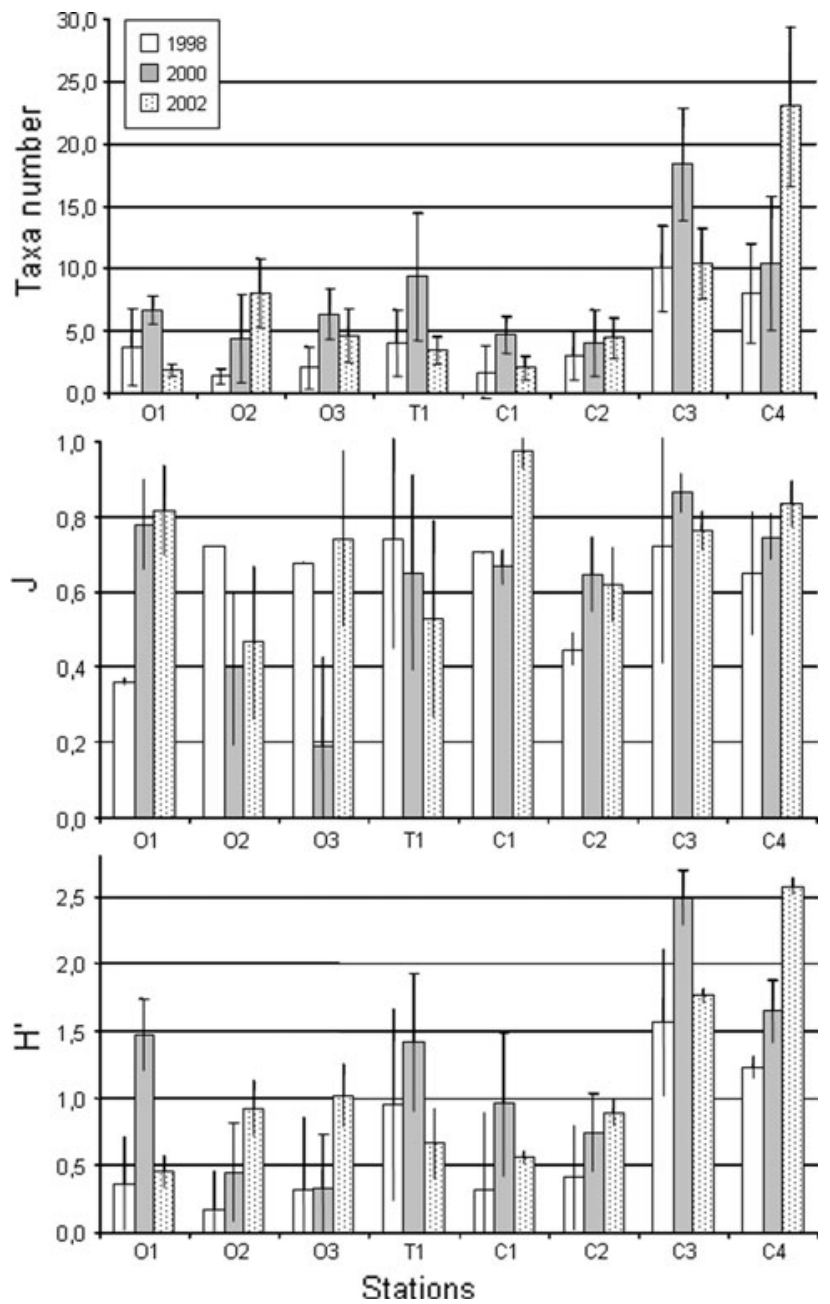

Fig. 3 Average mean and standard deviation of number of taxa, Pielou's evenness $(J)$ and Shannon diversity index $\left(H^{\prime}\right)$ of the macrofauna community in each station and sampling period

(average dissimilarity $=85.6 \%$ ) were based on the presence at channel mouth stations of taxa such as the venerid and mactrid molluscs or the phyllodocid polychaetes, while inner stations were mainly characterised by the high abundance of the spionid polychaetes. In 2000 sampling, the differences (average dissimilarity $=73.3 \%$ ) were based on similar taxa to 1998 sampling: e.g., presence at channel stations of taxa such as the venerid and corbulid molluscs and orbiniid polychaetes, and again, high abundance of spionids (average abundance of 1,054 individuals) and the anthurid crustaceans at inner areas. In 2002 sampling, the differences (average dissimilarity $=71.2 \%$ ) were based on a similar pattern to previous samplings again (e.g., high abundance of venerids and mactrids at outer areas), however, more taxa took part in these differences; there were higher abundance of cardiids at inner stations and spionids showed a more 
Table 3 Results of the two-way ANOVA for the spatio-temporal differences of univariate parameters

\begin{tabular}{lrllll}
\hline Parameter & $d f$ & MS & MS error & \multicolumn{1}{l}{$F$} & $P$ \\
\hline Abundance & & & & & \\
$\quad$ Station & 7 & 0.86 & 0.16 & 5.26 & 0.001 \\
$\quad$ Year & 2 & 1.26 & 0.16 & 7.68 & 0.001 \\
$\quad$ Interaction & 14 & 0.69 & 0.16 & 4.23 & 0.0003 \\
Taxa number & & & & & \\
$\quad$ Station & 7 & 0.56 & 0.33 & 16.64 & 0.00001 \\
$\quad$ Year & 2 & 0.46 & 0.33 & 13.74 & 0.00001 \\
$\quad$ Interaction & 14 & 0.12 & 0.33 & 3.44 & 0.0003 \\
$\quad J$ & & & & & \\
$\quad$ Station & 7 & 0.27 & 0.007 & 4.01 & 0.001 \\
$\quad$ Year & 2 & 0.38 & 0.007 & 5.68 & 0.005 \\
$\quad$ Interaction & 14 & 0.008 & 0.007 & 1.27 & NS \\
$H^{\prime}$ & & & & & \\
$\quad$ Station & 7 & 0.15 & 0.01 & 14.45 & 0.00001 \\
$\quad$ Year & 2 & 0.11 & 0.01 & 10.16 & 0.0001 \\
Interaction & 14 & 0.27 & 0.01 & 2.54 & 0.006 \\
\hline
\end{tabular}

NS not significant

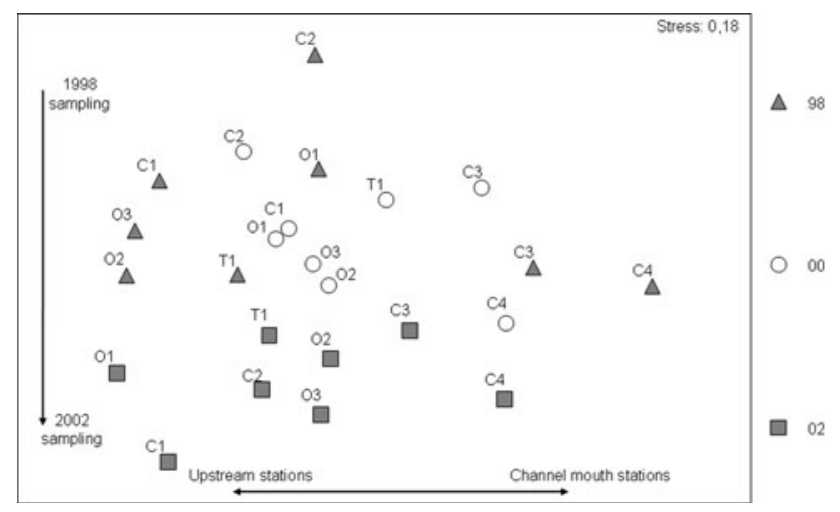

Fig. 4 MDS ordination for all stations and sampling periods, using Bray-Curtis similarities on taxa abundance. Horizontal and vertical arrows show the spatial and temporal pattern of station distributions homogeneous distribution along study zone. In terms of temporal changes (Table 5), SIMPER distinguished only between inner and outer areas. In the first ones, the main differences among sampling periods were based on higher abundance of spionids and anthurids in 2000 (e.g., spionid average abundance of 193, 1,054 and 248 individuals, respectively), and higher abundance of cardiids and the pectinariid polychaetes in 2002. At the outer channel area, the main differences were based on the presence of a greater number of taxa in 2000 and 2002 as opposed to 1998 sampling.

\section{Relationship between environmental and macrofauna}

The results of a global BIOENV analysis (all samplings pooled) indicated that the best correlations always occurred with \% sand, organic matter, phosphates and TOC (maximum correlations of 0.44 ). Separately, a BIOENV with 1998 data showed that the best correlations occurred with others variables such as $\mathrm{pH}, \mathrm{TOC}, \mathrm{Hg}$ or organic matter (maximum correlation of 0.77 with $\mathrm{pH}, \mathrm{TOC}, \mathrm{Hg}$ and $\mathrm{Cd}$ ). However, in 2000 and 2002 samplings, these best correlations were obtained with the variables related with granulometry and water characteristics (maximum correlations of 0.73 with $\mathrm{pH}$ and $\%$ sand in 2000 and of 0.79 with temperature, salinity, dissolved oxygen, fats and \% silt and clay in 2002).

The global CCA analysis (Fig. 6) indicated a similar distribution of stations to MDS ordination: channel mouth stations (C3 and C4) and the upstream area. The environmental variables that best explained the observed community distributions were $\mathrm{pH}$ and $\%$ of sand toward channel mouth and heavy metals, $\%$ organic matter and salinity toward inner points. The second axis was influenced by hydrocarbons and phosphates and discriminated between 2002 sampling and the others two periods. The Monte-Carlo test was significant for both axes $(P=0.01)$.
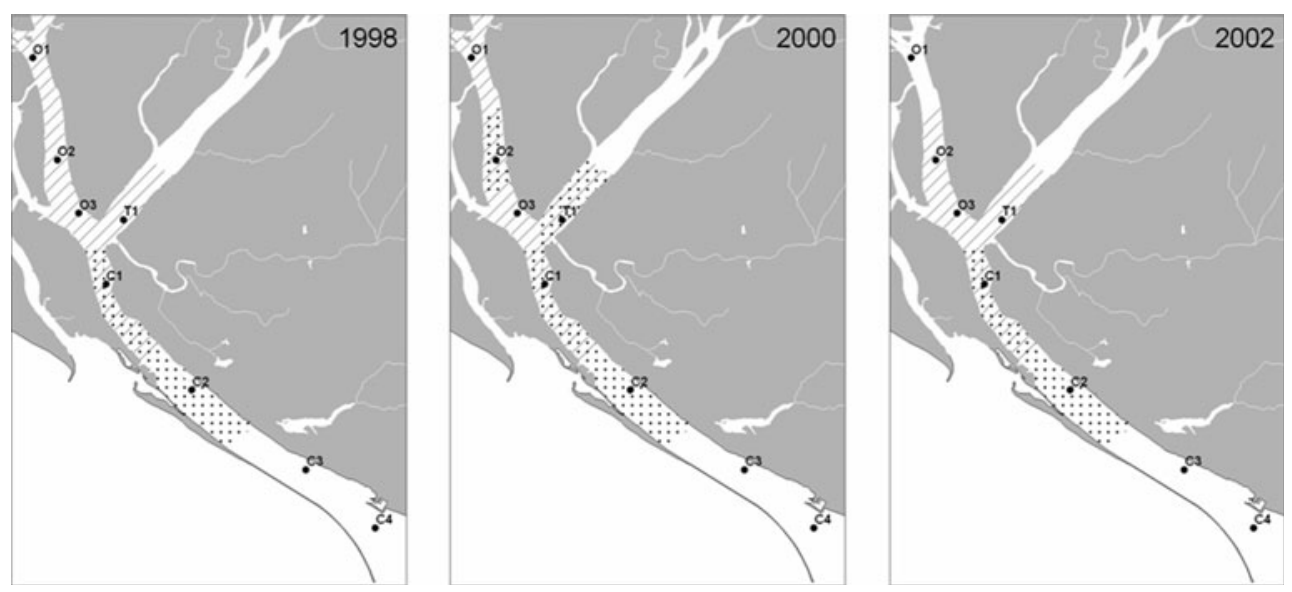

Fig. 5 Homogenous groups of stations according to one-way ANOSIM test in each sampling period 
Table 4 Average abundance (Av. abund) of the most relevant taxa of the stations located in the inner and outer areas in each sampling

\begin{tabular}{|c|c|c|c|c|c|c|}
\hline \multirow[t]{2}{*}{ Taxa } & \multicolumn{2}{|c|}{ Av. abund } & \multirow[t]{2}{*}{ Av. diss } & \multirow[t]{2}{*}{ Ratio } & \multirow{2}{*}{$\begin{array}{l}\text { Contrib } \\
(\%)\end{array}$} & \multirow{2}{*}{$\begin{array}{l}\text { Cum } \\
(\%)\end{array}$} \\
\hline & Inner & Outer & & & & \\
\hline \multicolumn{7}{|c|}{1998 (average dissimilarity $=85.6$ ) } \\
\hline Veneridae & 0 & 426.7 & 8.1 & 2.3 & 9.4 & 9.4 \\
\hline Phyllodocidae & 0 & 320 & 7.6 & 3.4 & 8.9 & 18.3 \\
\hline Mactridae & 0 & 193.3 & 6.2 & 1.8 & 7.2 & 25.5 \\
\hline Orbiniidae & 0 & 36.7 & 4.9 & 5.8 & 5.8 & 31.3 \\
\hline Spionidae & 193.3 & 10 & 4.9 & 1.8 & 5.7 & 37 \\
\hline Capitellidae & 0 & 10 & 3.6 & 5.4 & 4.2 & 41.2 \\
\hline Dexaminidae & 0 & 10 & 3.5 & 7.5 & 4.1 & 45.3 \\
\hline Phoronidea & 3.3 & 23.3 & 3.4 & 1.6 & 3.9 & 49.3 \\
\hline \multicolumn{7}{|c|}{2000 (average dissimilarity $=73.3$ ) } \\
\hline Spionidae & $1,054.4$ & 55.3 & 3.4 & 1.9 & 4.6 & 4.6 \\
\hline Orbiniidae & 1.1 & 78 & 2.9 & 2.6 & 4.1 & 8.7 \\
\hline Corbulidae & 0 & 69.3 & 2.8 & 2.1 & 3.8 & 12.5 \\
\hline Serpulidae & 0 & 50 & 2.7 & 6.9 & 3.8 & 16.3 \\
\hline Veneridae & 0 & 208 & 2.7 & 0.9 & 3.7 & 19.9 \\
\hline Mactridae & 2.2 & 42 & 2.4 & 2.7 & 3.3 & 23.3 \\
\hline Leptocheliidae & 2.2 & 50.7 & 2.3 & 2.3 & 3.2 & 26.4 \\
\hline Anthuridae & 132.2 & 30 & 2.2 & 1.4 & 2.9 & 29.4 \\
\hline Oligochaetes & 32.2 & 113.3 & 2.1 & 1.9 & 2.9 & 32.3 \\
\hline \multicolumn{7}{|c|}{2002 (average dissimilarity $=71.2$ ) } \\
\hline Mactridae & 0 & 329.5 & 3.1 & 2.8 & 4.3 & 4.3 \\
\hline Veneridae & 0 & 130.5 & 3 & 7.8 & 4.2 & 8.5 \\
\hline Oweniidae & 0 & 50.5 & 2.9 & 1.6 & 4 & 12.5 \\
\hline Oligochaetes & 0 & 80 & 2.6 & 0.9 & 3.6 & 16.1 \\
\hline Pectinariidae & 94 & 218 & 2.1 & 1.3 & 2.9 & 19.1 \\
\hline Nemertea & 5.3 & 57.5 & 1.9 & 1.6 & 2.7 & 21.8 \\
\hline Hesionidae & 0.7 & 14.5 & 1.9 & 1.6 & 2.7 & 24.5 \\
\hline Corbulidae & 0 & 12 & 1.9 & 6.1 & 2.6 & 27.2 \\
\hline Diogenidae & 0.7 & 29.5 & 1.8 & 2.6 & 2.6 & 29.7 \\
\hline Nassaridae & 0.7 & 27 & 1.8 & 2.6 & 2.6 & 32.3 \\
\hline Cardiidae & 486 & 92.5 & 1.8 & 1.3 & 2.5 & 34.8 \\
\hline Philinidae & 0 & 9.5 & 1.8 & 5.2 & 2.5 & 37.4 \\
\hline Spionidae & 248 & 319 & 1.7 & 1.8 & 2.4 & 39.8 \\
\hline
\end{tabular}

Taxa are listed in decreasing order according to its contribution to the average of the dissimilarity (Av. diss) between areas

\section{Discussion}

The natural gradients in salinity, granulometry and organic content have been described as the most important factors to explain the distribution and abundance of macrobenthic community in numerous estuarine ecosystems (Wolf 1983; Warwick et al. 1991; Attrill et al. 1996; Rakocinski et al. 1997; Ysebaert et al. 2002; Mucha et al. 2003; Sousa et al. 2006). In general, The Tinto-Odiel system has shown typical water and sediment characteristics of estuarine
Table 5 Interannual variation of the average abundance (Av. abund) of the most relevant taxa of the stations located in the inner and channel mouth stations

\begin{tabular}{|c|c|c|c|c|c|c|}
\hline Taxa & $\begin{array}{l}\text { Av. } \\
\text { abund }\end{array}$ & $\begin{array}{l}\text { Av. } \\
\text { abund }\end{array}$ & $\begin{array}{l}\text { Av. } \\
\text { diss }\end{array}$ & Ratio & $\begin{array}{l}\text { Contrib } \\
(\%)\end{array}$ & $\begin{array}{l}\text { Cum. } \\
(\%)\end{array}$ \\
\hline
\end{tabular}

Inner stations

\begin{tabular}{lrrrrrr}
\hline & 1998 & \multicolumn{1}{c}{2000} & \multicolumn{4}{c}{ (average dissimilarity $=69.24)$} \\
\hline Anthuridae & 0.00 & 132.22 & 7.38 & 2.68 & 10.66 & 10.66 \\
Nereididae & 1.11 & 60.00 & 5.84 & 2.65 & 8.43 & 19.09 \\
Spionidae & 193.33 & $1,054.44$ & 5.09 & 1.46 & 7.35 & 26.44 \\
Oligochaetes & 88.89 & 32.22 & 4.99 & 1.90 & 7.20 & 33.65 \\
\hline & 1998 & 2002 & (average & dissimilarity $=72.78)$ \\
\hline Cardiidae & 5.56 & 486.00 & 9.82 & 1.59 & 13.49 & 13.49 \\
Pectinariidae & 0.00 & 94.00 & 6.85 & 1.43 & 9.42 & 22.90 \\
Spionidae & 193.33 & 248.00 & 5.24 & 1.61 & 7.19 & 30.10 \\
Nephtyidae & 11.11 & 24.67 & 4.49 & 1.08 & 6.17 & 36.27 \\
\hline & 2000 & 2002 & $($ average dissimilarity $=69.56)$ \\
\hline Spionidae & $1,054.44$ & 248.00 & 5.86 & 1.43 & 8.42 & 8.42 \\
Nereididae & 60.00 & 0.67 & 5.24 & 2.53 & 7.53 & 15.95 \\
Anthuridae & 132.22 & 4.67 & 5.17 & 1.46 & 7.43 & 23.38 \\
Pectinariidae & 0.00 & 94.00 & 4.64 & 1.48 & 6.67 & 30.05 \\
Capitellidae & 36.67 & 0.00 & 4.20 & 1.45 & 6.03 & 36.09 \\
Oligochaetes & 32.22 & 0.00 & 4.17 & 1.82 & 6.00 & 42.08 \\
Cardiidae & 28.89 & 486.00 & 3.78 & 1.13 & 5.43 & 47.52
\end{tabular}

Channel mouth stations

\begin{tabular}{lrrlrlr}
\hline & 1998 & 2000 & \multicolumn{3}{l}{ (average dissimilarity $=61.55)$} \\
\hline Veneridae & 426.67 & 208.00 & 2.55 & 1.48 & 4.14 & 4.14 \\
Corophiidae & 0.00 & 59.33 & 2.46 & 4.46 & 3.99 & 8.13 \\
Leptocheliidae & 0.00 & 50.67 & 2.31 & 3.82 & 3.76 & 11.89 \\
Phyllodocidae & 320.00 & 5.33 & 2.26 & 1.80 & 3.67 & 15.56 \\
Phoronidea & 23.33 & 0.00 & 2.14 & 5.57 & 3.47 & 19.03 \\
Oligochaetes & 0.00 & 113.33 & 1.77 & 0.87 & 2.87 & 21.91 \\
Serpulidae & 3.33 & 50.00 & 1.71 & 1.68 & 2.78 & 24.69 \\
Corbulidae & 23.33 & 69.33 & 1.69 & 1.34 & 2.74 & 27.43 \\
Anomiidae & 0.00 & 8.67 & 1.62 & 11.45 & 2.64 & 30.07 \\
\hline & 1998 & 2002 & $($ average & dissimilarity $=72.88)$ \\
\hline Pectinariidae & 0.00 & 218.00 & 3.40 & 5.08 & 4.67 & 4.67 \\
Spionidae & 10.00 & 319.00 & 2.65 & 2.19 & 3.63 & 8.30 \\
Cardiidae & 0.00 & 92.50 & 2.58 & 1.44 & 3.54 & 11.84 \\
Oweniidae & 0.00 & 50.50 & 2.28 & 1.58 & 3.13 & 14.97 \\
Phyllodocidae & 320.00 & 4.50 & 2.13 & 1.64 & 2.92 & 17.89 \\
Oligochaetes & 0.00 & 80.00 & 2.00 & 0.87 & 2.75 & 20.64 \\
Phoronidea & 23.33 & 0.00 & 1.96 & 3.13 & 2.69 & 23.33 \\
Hesionidae & 0.00 & 14.50 & 1.76 & 2.09 & 2.42 & 25.75 \\
Corophiidae & 0.00 & 32.00 & 1.76 & 9.02 & 2.41 & 28.16 \\
Diogenidae & 0.00 & 29.50 & 1.74 & 10.13 & 2.38 & 30.54 \\
\hline
\end{tabular}


Table 5 continued

\begin{tabular}{lrrlllr}
\hline & 2000 & \multicolumn{1}{c}{2002} & \multicolumn{3}{c}{ (average dissimilarity $=61.23)$} \\
\hline Pectinariidae & 0.00 & 218.00 & 2.72 & 6.29 & 4.44 & 4.44 \\
Serpulidae & 50.00 & 0.00 & 1.83 & 3.86 & 2.98 & 7.42 \\
Oweniidae & 0.00 & 50.50 & 1.79 & 1.67 & 2.92 & 10.34 \\
Veneridae & 208.00 & 130.50 & 1.62 & 1.79 & 2.64 & 12.98 \\
Orbiniidae & 78.00 & 5.00 & 1.59 & 1.36 & 2.60 & 15.59 \\
Cardiidae & 4.00 & 92.50 & 1.43 & 1.16 & 2.34 & 17.92 \\
Oligochaetes & 113.33 & 80.00 & 1.42 & 0.91 & 2.33 & 20.25 \\
Capitellidae & 15.33 & 105.00 & 1.36 & 3.36 & 2.22 & 22.47 \\
Spionidae & 55.33 & 319.00 & 1.24 & 1.44 & 2.03 & 24.50 \\
Mactridae & 42.00 & 329.50 & 1.22 & 4.18 & 1.99 & 26.49 \\
\hline
\end{tabular}

Taxa are listed in decreasing order according to its contribution to the average of the dissimilarity (Av. diss) between sampling periods

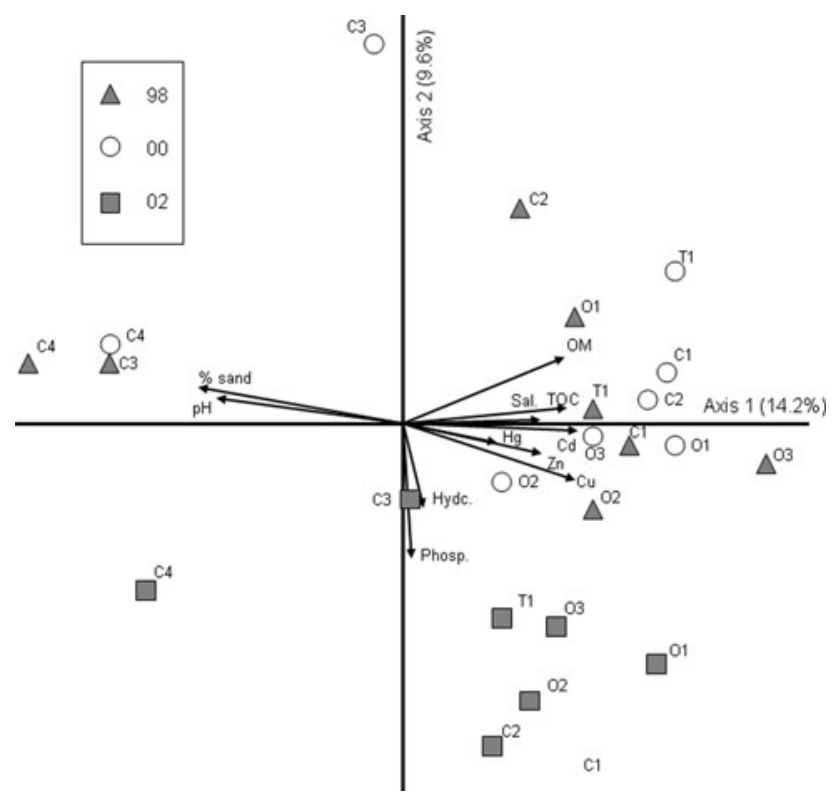

Fig. 6 CCA analysis plot for all stations and sampling periods from selected parameters of water and sediment: $\mathrm{pH}$, salinity $(\mathrm{Sal}), \%$ of sand, heavy metals $(\mathrm{Hg}, \mathrm{Zn}, \mathrm{Cu}$ and $\mathrm{Cd}$ ), hydrocarbons (Hydc.), phosphates (Phosp.), organic matter content $(O M)$ and total organic carbon $(T O C)$. The percentage of variability explained by the axis is given

areas at the spatial scale. This is corroborated through PCA analysis in which the stations were separated according to a natural gradient from estuarine to marine environment.

A main characteristic of Tinto-Odiel system is the high concentration of some heavy metals in sediment, in comparison with other European rivers (Elbaz-Poulichet et al. 2001). For example, the maximum value of $\mathrm{Zn}$ in the present study was $6,378 \mathrm{ppm}$ (Station $\mathrm{C} 1$ in 2000 sampling), which is much higher than $169 \mathrm{ppm}$ in the Seine estuary, the most heavily contaminated French river
(Dauvin 2008) or $>200 \mathrm{ppm}$ in the Douro estuary (Portugal: Mucha et al. 2005). In other geographically near estuary, the Guadiana River, the concentrations only reached maximum values of 149 ppm (Sánchez-Moyano et al. 2003). This last estuary, opposite to Tinto-Odiel, is located in an extensive agricultural zone, with few inhabitants and the main disturbances are moderate urban sewages. The same pattern was observed for other metals such as $\mathrm{Cu}: 2,448 \mathrm{ppm}$ in Tinto-Odiel system; $44.1 \mathrm{ppm}$ in the Seine; $80 \mathrm{ppm}$ in the Douro and $20 \mathrm{ppm}$ in the Guadiana. For both metals, the geoaccumulation indices showed highly or very highly polluted level (except at the mouth river stations). These data are in agreement with the results obtained in this zone by Ruiz (2001). According to Ruiz et al. (1998), the origin of these heavy metals is industrial discharges (70-80\%), acid-mine drainage (20-30\%) and minor contributions from urban effluents, while near the mouth, the sediments are periodically dredged and have not had sufficient time to accumulate a high metal content, by which they show very low geoaccumulation indices for all the metals. Furthermore, industrial dumping corrective measures have resulted in remarkable local improvement but have not had a significant effect on the global contamination in the estuary (Sáinz et al. 2003).

In spite of the historical knowledge of the high level of contamination of the Tinto-Odiel system, there is only a single study on the structure of macrofauna communities (Cano and García 1987). All estuaries are characterised by a soft-bottom macrobenthic communities impoverished in relation to those from marine sediments (Wolf 1983; Warwick et al. 1991; Rakocinski et al. 1997; Peeters et al. 2000), and this can difficult the interpretation of the effects of pollution on the structure of the animal communities. However, it has been demonstrated that the human impact increases this impoverishment in species diversity, for example, Marques et al. (1993) observed that the subtidal macrofauna in the Mondego Estuary appeared to be clearly impoverished compared to other Portuguese estuary much less exposed to human impacts.

In the present study, and according to MDS and CCA analysis, the different stations were distributed according to a natural gradient from estuarine to marine environments. Independently of sampling year, the structure of the community has been mainly determined by granulometry and the organic matter content in sediment, which are considered as the major structuring factors for the natural macrobenthic distribution pattern together with salinity (Warwick et al. 1991; Ysebaert et al. 2002; Mucha et al. 2003; Sousa et al. 2006). Community variables such as Shannon Diversity or taxa number showed the typical trend of estuaries, with a progressive increment toward the mouth river, but in a wide interval (e.g., $H^{\prime}=0.96$ and only 2 families at $\mathrm{O} 1$ until $H^{\prime}=2.84$ and 46 families at 
C4), which seem to demonstrate a strong stress on communities, at least at inner areas. High concentrations of heavy metals have been associated with low number of taxa and diversity in other estuaries (Mucha et al. 2005). In fact, high concentrations of metals, together with the granulometric composition and water characteristics, has been one of the main factors in the ordinations of stations through Odiel-Tinto system, although it is not possible to determine separately the effect from each one of these factors. The macrobenthic community was dominated by polychaetes and, especially, by small size opportunistic taxa such spionids; while the crustaceans, the most sensitive marine animal group to pollution (Warwick 2001; Dauvin 2008), were the least abundant.

Recovery of marine ecosystems from pollution is inevitably a long-term process (Hawkins et al. 2002). A 4-year sampling period appears to be too short-term to establish definitive conclusions on possible improvements of the system after the implementation of corrective measures. This is particularly true for grossly polluted estuaries, which are organically enriched from sewage discharges, and receive heavy metals and other contaminants (Matthiessen and Law 2002; Essink 2003; González-Oreja and Saiz-Salinas 2003). Compared to results obtained in 19801981 from Cano and García (1987), the diversity values or richness were very similar to those obtained in 1998. However, an increase in values of diversity index or number of taxa was observed since 1998-2002, and this "improvement" has been more notable during the last sampling period. The main difference between 1980 and 1981 study and the present work has been a drastic decrease in the nereidid polychaetes (especially Hediste diversicolor), which were replaced by small size spionids. $H$. diversicolor is described as a species indifferent to pollution (Pearson and Rosenberg 1978), even in grossly polluted sediment (González-Oreja and Saiz-Salinas 2003), so that it is difficult to attribute some cause to this particular change in the community composition.

Since 2000 sampling, other changes have been a high abundance of the anthurid isopods (exclusively Cyathura carinata) and greater richness and abundance of crustaceans. According Warwick and Clarke (1993), the structure of estuarine soft-bottom communities generally shifts with environmental stress to one that is less dominated by crustaceans and more dominated by polychaetes or oligochaetes. Furthermore, pericarid crustaceans appeared to be sensitive to sediment contamination, except some opportunistic amphipod such as Corophium (Rakocinski et al. 1997). Parallel, a high abundance of the cardiid molluscs (group represented here exclusively by Cerastoderma edule) occurred in the inner zone since 2000 sampling (with peak of abundance in 2002 period). The exclusion or restriction of some species of bivalves, such as $C$. edule, in the Fal estuary (UK) has been attributed in part to a strong copper and zinc pollution (Matthiessen and Law 2002), just as it happened in Odiel-Tinto estuary.

Considering all information, some changes have been noticed along the sampling period. There were (1) slight increment in richness and diversity; (2) higher presence of molluscs and crustaceans in the inner zones; (3) a more homogeneous spatial distribution of opportunistic taxa (e.g., Spionidae); (4) a higher number of taxa characterising the differences among the estuarine sectors. However, the period is too short to conclude that these changes are the consequence of a true improvement of the environment or to natural cycles. In this sense, it would be necessary the establishment of a long-term monitoring programme to study the evolution of the macrofauna communities to state whether the corrective measures could achieve a future remarkable improvement of this environment. This programme should focus on the study of macrobenthic community structure and on selected parameters (e.g., sediment composition, organic content, salinity and $\mathrm{Cu}$ and $\mathrm{Zn}$ ), which have been the major structuring factors for these communities.

Acknowledgments We thank to Dr. Francisco Estacio and Emilio García-Adiego for their assistance in the field and in the laboratory; the crew members of the ship AMA 6 (Mariano Campoy, Blas Brito and José María Ávila), and Consejería de Medio Ambiente of the Government of Andalusia for financial support (projects OG-104/01, OG-013/03).

\section{Appendix}

See Table 6. 
Table 6 Abundance (ind. $\mathrm{m}^{-2}$ ) of the taxa identified in the Odiel-Tinto estuary in each station and sampling period

\begin{tabular}{|c|c|c|c|c|c|c|c|c|c|c|c|c|c|c|c|c|c|c|c|c|c|c|c|c|}
\hline \multirow[t]{2}{*}{ Taxa } & \multicolumn{8}{|c|}{1998} & \multicolumn{8}{|c|}{2000} & \multicolumn{8}{|c|}{2002} \\
\hline & $\mathrm{O} 1$ & $\mathrm{O} 2$ & $\mathrm{O} 3$ & $\mathrm{~T} 1$ & $\mathrm{C} 1$ & $\mathrm{C} 2$ & $\mathrm{C} 3$ & $\mathrm{C} 4$ & O1 & $\mathrm{O} 2$ & $\mathrm{O} 3$ & $\mathrm{~T} 1$ & $\mathrm{C} 1$ & $\mathrm{C} 2$ & $\mathrm{C} 3$ & $\mathrm{C} 4$ & O1 & $\mathrm{O} 2$ & $\mathrm{O} 3$ & $\mathrm{~T} 1$ & $\mathrm{C} 1$ & $\mathrm{C} 2$ & $\mathrm{C} 3$ & $\mathrm{C} 4$ \\
\hline CNIDARIA & 0 & 0 & 0 & 0 & 13 & 0 & 0 & 0 & 0 & 0 & 0 & 0 & 0 & 7 & 0 & 0 & 0 & 0 & 0 & 0 & 0 & 0 & 0 & \\
\hline \multicolumn{25}{|c|}{ PLATYHELMINTHES } \\
\hline Turbellaria & 0 & 0 & 0 & 0 & 0 & 0 & 0 & 0 & 0 & 0 & 0 & 7 & 0 & 0 & 0 & 0 & 0 & 0 & 0 & 0 & 0 & 0 & 0 & \\
\hline NEMERTEA & 0 & 0 & 0 & 0 & 0 & 0 & 33 & 0 & 0 & 7 & 7 & 0 & 0 & 20 & 0 & 16 & 0 & 24 & 0 & 4 & 0 & 4 & 20 & \\
\hline PHORONIDEA & 13 & 0 & 0 & 7 & 0 & 0 & 13 & 33 & 0 & 0 & 0 & 0 & 0 & 0 & 0 & 0 & 0 & 0 & 0 & 0 & 0 & 0 & 0 & \\
\hline \multicolumn{25}{|l|}{ ANNELIDA } \\
\hline Oligochaeta & 220 & 0 & 0 & 0 & 0 & 313 & 0 & 0 & 20 & 0 & 20 & 120 & 7 & 27 & 227 & 0 & 0 & 0 & 0 & 0 & 0 & 0 & 160 & \\
\hline \multicolumn{25}{|l|}{ Polychaeta } \\
\hline Capitellidae & 0 & 0 & 0 & 0 & 0 & 0 & 7 & 13 & 167 & 7 & 13 & 13 & 20 & 0 & 27 & 4 & 0 & 0 & 0 & 0 & 0 & 0 & 0 & 210 \\
\hline Cirratulidae & 0 & 0 & 0 & 0 & 0 & 0 & 0 & 0 & 0 & 0 & 0 & 0 & 0 & 0 & 60 & 0 & 0 & 8 & 28 & 0 & 0 & 8 & 0 & \\
\hline Chrysopetalidae & 0 & 0 & 0 & 0 & 0 & 0 & 0 & 0 & 0 & 0 & 0 & 7 & 0 & 0 & 0 & 0 & 0 & 0 & 0 & 0 & 0 & 0 & 0 & \\
\hline Eunicidae & 0 & 0 & 0 & 0 & 0 & 0 & 0 & 0 & 0 & 0 & 0 & 0 & 0 & 0 & 13 & 0 & 0 & 0 & 0 & 0 & 0 & 0 & 0 & \\
\hline Glyceridae & 0 & 0 & 0 & 0 & 0 & 0 & 7 & 7 & 0 & 7 & 0 & 0 & 0 & 0 & 20 & 4 & 0 & 8 & 0 & 0 & 0 & 0 & 0 & 125 \\
\hline Hesionidae & 0 & 0 & 0 & 0 & 0 & 27 & 0 & 0 & 0 & 0 & 0 & 0 & 0 & 0 & 47 & 0 & 0 & 0 & 0 & 0 & 0 & 4 & 24 & \\
\hline Magelonidae & 0 & 0 & 0 & 0 & 0 & 0 & 0 & 0 & 0 & 0 & 0 & 0 & 0 & 0 & 0 & 0 & 0 & 0 & 0 & 0 & 0 & 0 & 0 & 65 \\
\hline Nephtyidae & 20 & 7 & 7 & 7 & 0 & 27 & 33 & 53 & 0 & 0 & 20 & 13 & 0 & 0 & 27 & 28 & 0 & 40 & 44 & 40 & 0 & 24 & 76 & 100 \\
\hline Nereididae & 7 & 0 & 0 & 0 & 0 & 0 & 0 & 0 & 73 & 33 & 20 & 193 & 27 & 13 & 7 & 4 & 0 & 0 & 4 & 0 & 0 & 0 & 4 & \\
\hline Onuphidae & 0 & 0 & 0 & 0 & 0 & 0 & 0 & 0 & 0 & 0 & 0 & 0 & 0 & 7 & 0 & 0 & 0 & 20 & 20 & 0 & 0 & 0 & 0 & 35 \\
\hline Orbiniidae & 0 & 0 & 0 & 0 & 0 & 0 & 27 & 47 & 0 & 0 & 0 & 7 & 0 & 0 & 40 & 116 & 0 & 8 & 0 & 0 & 0 & 0 & 0 & 10 \\
\hline Oweniidae & 7 & 0 & 0 & 0 & 0 & 7 & 0 & 0 & 0 & 0 & 0 & 0 & 0 & 0 & 0 & 0 & 0 & 0 & 0 & 0 & 0 & 0 & 96 & \\
\hline Paraonidae & 0 & 0 & 0 & 0 & 0 & 0 & 0 & 0 & 0 & 0 & 0 & 33 & 13 & 7 & 0 & 0 & 0 & 0 & 0 & 0 & 0 & 0 & 0 & \\
\hline Pectinariidae & 0 & 0 & 0 & 0 & 0 & 0 & 0 & 0 & 0 & 0 & 0 & 0 & 0 & 0 & 0 & 0 & 0 & 108 & 16 & 4 & 20 & 416 & 156 & 280 \\
\hline Phyllodocidae & 0 & 0 & 0 & 0 & 0 & 0 & 587 & 53 & 0 & 0 & 0 & 0 & 0 & 0 & 7 & 4 & 0 & 0 & 0 & 0 & 0 & 0 & 4 & \\
\hline Pilargididae & 0 & 0 & 0 & 0 & 0 & 13 & 0 & 0 & 0 & 0 & 0 & 0 & 0 & 0 & 113 & 0 & 0 & 0 & 0 & 0 & 0 & 0 & 0 & 10 \\
\hline Pisionidae & 0 & 0 & 0 & 0 & 0 & 0 & 13 & 0 & 0 & 0 & 0 & 0 & 0 & 0 & 0 & 8 & 0 & 0 & 0 & 0 & 0 & 0 & 0 & \\
\hline Poecilochaetidae & 0 & 0 & 0 & 0 & 0 & 0 & 27 & 0 & 0 & 0 & 0 & 0 & 0 & 0 & 0 & 4 & 0 & 0 & 0 & 0 & 0 & 0 & 0 & \\
\hline Polynoidae & 0 & 0 & 0 & 0 & 0 & 0 & 0 & 0 & 7 & 0 & 0 & 0 & 0 & 0 & 0 & 0 & 0 & 12 & 0 & 0 & 0 & 4 & 4 & \\
\hline Sabellidae & 0 & 0 & 0 & 0 & 0 & 0 & 0 & 0 & 0 & 0 & 0 & 0 & 0 & 0 & 0 & 0 & 0 & 12 & 0 & 0 & 0 & 0 & 0 & \\
\hline Saccocirridae & 0 & 0 & 0 & 0 & 0 & 0 & 7 & 0 & 0 & 0 & 0 & 0 & 0 & 0 & 0 & 0 & 0 & 0 & 0 & 0 & 0 & 0 & 0 & \\
\hline Serpulidae & 0 & 0 & 0 & 0 & 0 & 0 & 7 & 0 & 0 & 0 & 0 & 0 & 0 & 0 & 80 & 20 & 0 & 0 & 0 & 0 & 0 & 0 & 0 & \\
\hline Sigalionidae & 0 & 0 & 0 & 0 & 0 & 0 & 0 & 0 & 0 & 0 & 0 & 93 & 0 & 0 & 100 & 0 & 0 & 0 & 4 & 0 & 0 & 0 & 0 & \\
\hline Spionidae & 533 & 93 & 180 & 153 & 193 & 7 & 20 & 0 & 593 & 873 & 2,567 & 1,540 & 553 & 200 & 107 & 4 & 32 & 876 & 4 & 464 & 8 & 104 & 148 & 490 \\
\hline Syllidae & 0 & 0 & 0 & 0 & 0 & 0 & 0 & 7 & 0 & 0 & 0 & 0 & 0 & 0 & 40 & 0 & 0 & 0 & 0 & 0 & 0 & 0 & 0 & \\
\hline Terebellidae & 0 & 0 & 0 & 0 & 0 & 0 & 0 & 0 & 0 & 0 & 0 & 0 & 0 & 0 & 13 & 0 & 0 & 0 & 0 & 0 & 0 & 0 & 0 & \\
\hline
\end{tabular}

CRUSTACEA

Amphipoda

Ampeliscidae

Aoridae

Caprellidae

$\begin{array}{lllllllllllllllll}20 & 0 & 7 & 13 & 0 & 0 & 0 & 0 & 0 & 0 & 0 & 180 & 0 & 0 & 0 & 0 & 0\end{array}$

$\begin{array}{lllllll}0 & 0 & 0 & 0 & 0 & 4 & 10\end{array}$

Caprellidae

$\begin{array}{lllllllllllllllll}0 & 0 & 0 & 0 & 0 & 0 & 0 & 0 & 0 & 0 & 13 & 0 & 0 & 0 & 27 & 0 & 0\end{array}$

$\begin{array}{llllllll}0 & 0 & 0 & 0 & 0 & 0 & 0 \\ 0 & 0 & 4 & 0 & 0 & 8 & 5\end{array}$

Dexaminidae

$\begin{array}{lllll}20 & 0 & 0 & 33 & 13\end{array}$

Gammaridae

$\begin{array}{lllllllllllllllll}0 & 0 & 0 & 0 & 0 & 0 & 13 & 7 & 0 & 0 & 0 & 0 & 0 & 0 & 0 & 4 & 0\end{array}$

Haustoridae

Ischyroceridae

Oedicerotidae

Cumacea

Bodotriidae

Decapoda

Alpheidae

Crangonidae

$$
\begin{array}{llllllllll}
7 & 0 & 0 & 13 & 133 & 0 & 27 & 0 & 7 & 20
\end{array}
$$

$\begin{array}{llllll}240 & 20 & 0 & 0 & 8 & 0\end{array}$

$\begin{array}{lllllll}12 & 4 & 0 & 0 & 0 & 4 & 60\end{array}$

$$
\begin{array}{lllllllllllllllll}
0 & 0 & 0 & 0 & 0 & 0 & 0 & 0 & 0 & 0 & 0 & 0 & 0 & 0 & 0 & 12 & 0
\end{array}
$$

$\begin{array}{lllllll}0 & 0 & 0 & 0 & 0 & 0 & 0\end{array}$

$\begin{array}{lllllll}4 & 0 & 0 & 0 & 0 & 0 & 5\end{array}$ $\begin{array}{lllllll}0 & 0 & 0 & 0 & 0 & 0 & 0\end{array}$ $\begin{array}{rrrrrrrrrrrrrrrrrrrrrrrrrrrr}0 & 0 & 0 & 0 & 0 & 0 & 0 & 0 & 0 & 0 & 0 & 0 & 0 & 0 & 0 & 0 & 0 & 0 & 0 & 0 & 0 & 0 & 0 & 5\end{array}$ Diogenidae

$\begin{array}{llllllllllllllllllllllll}0 & 0 & 0 & 0 & 0 & 0 & 0 & 0 & 0 & 0 & 0 & 0 & 0 & 0 & 0 & 4 & 0 & 0 & 0 & 0 & 0 & 0 & 0 & 10\end{array}$ $\begin{array}{lllllllllllllllllllllllll}0 & 0 & 0 & 0 & 0 & 0 & 0 & 0 & 0 & 0 & 0 & 0 & 0 & 0 & 40 & 0 & 0 & 0 & 0 & 0 & 0 & 0 & 0 & 0\end{array}$ $\begin{array}{llllllllllllllllllllllll}0 & 0 & 0 & 0 & 0 & 0 & 0 & 0 & 0 & 0 & 0 & 0 & 0 & 0 & 0 & 16 & 0 & 8 & 0 & 20 & 8 & 4 & 4 & 0\end{array}$ 
Table 6 continued

\begin{tabular}{|c|c|c|c|c|c|c|c|c|c|c|c|c|c|c|c|c|c|c|c|c|c|c|c|c|c|c|}
\hline \multirow[t]{2}{*}{ Taxa } & \multicolumn{8}{|c|}{1998} & \multicolumn{9}{|c|}{2000} & \multicolumn{9}{|c|}{2002} \\
\hline & $\mathrm{O} 1$ & $\mathrm{O} 2$ & $\mathrm{O} 3$ & $\mathrm{~T} 1$ & $\mathrm{C} 1$ & $\mathrm{C} 2$ & $\mathrm{C} 3$ & $\mathrm{C} 4$ & $\mathrm{O} 1$ & $\mathrm{O} 2$ & $\mathrm{O} 3$ & & T1 & $\mathrm{C} 1$ & $\mathrm{C} 2$ & $\mathrm{C} 3$ & $\mathrm{C} 4$ & O1 & $\mathrm{O} 2$ & & $\mathrm{O} 3$ & $\mathrm{~T} 1$ & $\mathrm{C} 1$ & $\mathrm{C} 2$ & $\mathrm{C} 3$ & $\mathrm{C} 4$ \\
\hline Dorippidae & 0 & 0 & 0 & ( & 0 & 0 & 0 & 0 & 0 & 0 & & 0 & 0 & 0 & 0 & 0 & 0 & 0 & & 0 & 0 & 0 & 0 & 0 & 0 & 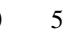 \\
\hline Grapsidae & 0 & 0 & 0 & c & 0 & 0 & 0 & 0 & 0 & 0 & & 0 & 0 & 0 & 0 & 0 & 4 & 0 & & 0 & 0 & 0 & 0 & 0 & 0 & 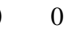 \\
\hline Hippolytidae & 0 & 0 & 0 & c & 0 & 0 & 0 & 0 & 0 & 0 & & 0 & 0 & 0 & 0 & 27 & 0 & 0 & & 0 & 0 & 0 & 0 & 0 & 0 & 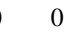 \\
\hline Penaeidae & 0 & 0 & 0 & c & 0 & 0 & 0 & 0 & 7 & 0 & & 0 & 0 & 0 & 0 & 0 & 0 & 0 & & 0 & 0 & 0 & 0 & 0 & 0 & 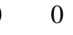 \\
\hline Portunidae & 0 & 0 & 0 & ( & 0 & 0 & 0 & 0 & 0 & 0 & & 0 & 0 & 0 & 0 & 7 & 0 & 0 & & 0 & 0 & 0 & 0 & 0 & 0 & 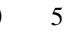 \\
\hline Processidae & 0 & 0 & 0 & c & 0 & 0 & 0 & 0 & 0 & 0 & & 0 & 7 & 0 & 0 & 13 & 0 & 0 & & 0 & 0 & 0 & 0 & 0 & 0 & 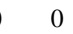 \\
\hline Upogebiidae & 0 & 0 & 0 & c & 0 & 0 & 0 & 0 & 0 & 0 & & 0 & 0 & 0 & 0 & 0 & 0 & 0 & & 0 & 0 & 0 & 0 & 0 & 0 & 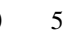 \\
\hline Xanthidae & 0 & 0 & 0 & c & 0 & 0 & 0 & 0 & 0 & 0 & & 0 & 0 & 0 & 0 & 7 & 0 & 0 & & 0 & 0 & 0 & 0 & 0 & 0 & \\
\hline
\end{tabular}

Isopoda

Anthuridae

Gnathiidae

Chaetiliidae

Sphaeromatidae

$$
\begin{array}{lllll}
0 & 0 & 0 & 0 & 0
\end{array}
$$

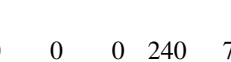

Mysidacea

Tanaidacea

Leptocheliidae

ECHINODERMATA

\section{Echinoidea}

Lovenidae

Ophiuroidea

Amphiuridae

Ophiuridae

MOLLUSCA

Bivalvia

Anomiidae

Cardiidae

$\begin{array}{lllllllll}0 & 0 & 7 & 0 & 0 & 0 & 0 & 0 & 0\end{array}$

$$
\begin{array}{lllllllllll}
0 & 0 & 0 & 0 & 0 & 0 & 0 & 0 & 0 & 0 & 0
\end{array}
$$

$\begin{array}{rrrrrrrrrr}27 & 0 & 0 & 0 & 0 & 0 & 33 & 0 & 0 & 0\end{array}$

Corbulidae

00

$\begin{array}{lllllll}0 & 0 & 0 & 13 & 0 & 0 & 0\end{array}$

$\begin{array}{rrrrrr}327 & 140 & 7 & 60 & 0 & 0 \\ 0 & 0 & 0 & 0 & 0 & 0 \\ 0 & 0 & 0 & 7 & 0 & 0 \\ 0 & 0 & 0 & 0 & 0 & 0 \\ 0 & 0 & 0 & 0 & 24 & 0\end{array}$

$\begin{array}{rrrrrrr}20 & 4 & 4 & 0 & 0 & 8 & 0 \\ 0 & 0 & 0 & 0 & 0 & 0 & 0 \\ 0 & 0 & 0 & 0 & 0 & 0 & 0 \\ 0 & 0 & 0 & 0 & 0 & 0 & 0 \\ 0 & 0 & 0 & 0 & 0 & 0 & 0\end{array}$

0

Donacidae

Glycimerididae

Hiatellidae

Mactridae

Montacutidae

Mytilidae

Ostreidae

Pandoridae

Pharidae

Semelidae

Tellinidae

Thracidae

Venereidae

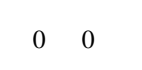

\section{(0) 0}

\section{0}




\section{References}

Attrill MJ, Rundle SD, Myles Thomas R (1996) The influence of drought-induced low freshwater flow on an upper-estuarine macroinvertebrate community. Water Res 30:261-268

Bermejo JCS, Beltran R, Ariza JLG (2003) Spatial variations of heavy metals contamination in sediments from Odiel river (Southwest Spain). Environ Inter 29:69-77

Boesch DF, Rosenberg R (1981) Response to stress in marine benthic communities. In: Barrett GW, Rosenberg R (eds) Stress effects on natural ecosystems. John Wiley, New York, pp 179-200

Boyoucos CJ (1934) The hydrometer method for making mechanical analysis of soils. Soils Sci 38:335-343

Cano J, García T (1987) Macrobentos endofaunal de la Ría de Huelva. Cuad Marisq Publ Téc 11:71-91

Clarke KR (1993) Non parametric multivariate analyses of changes in community structure. Austr J Ecol 18:117-143

Clarke KR, Ainsworth M (1993) A method of linking multivariate community structure to environmental variables. Mar Ecol Prog Ser 92:205-219

Clarke KR, Green RH (1988) Statistical design and analysis for a 'biological effects' study. Mar Ecol Prog Ser 46:213-226

Comín FA, Menéndez M, Herrera JA (2004) Spatial and temporal scales for monitoring coastal aquatic ecosystems. Aquat Conserv $14: 5-17$

Dauvin JC (2008) Effects of heavy metal contamination on the macrobenthic fauna in estuaries: The case of the Seine estuary. Mar Pollut Bull 57:160-169

Dauvin JC, Desroy N, Janson AL, Vallet C, Duhamel S (2006) Recent changes in estuarine benthic and suprabenthic communities resulting from the development of harbour infrastructure. Mar Pollut Bull 53:80-90

De Paz L, Neto JM, Marques JC, Laborda AJ (2008) Response of intertidal macrobenthic communities to long term human induced changes in the Eo estuary (Asturias, Spain): Implications for environmental management. Mar Environ Res 66:288299

Drake P, Baldó F, Saenz V, Arias AM (1999) Macrobenthic Community Structure in Estuarine Pollution Assessment on the Gulf of Cádiz (SW Spain): is the Phylum-level Meta-analysis Approach Applicable? Mar Pollut Bull 38:1038-1047

Elbaz-Poulichet F, Braungardt C, Achterberg E, Morley N, Cossa D, Beckers JM, Nomérange P, Cruzado A, Leblanc M (2001) Metal biogeochemistry in the Tinto-Odiel rivers (Southern Spain) and in the Gulf of Cadiz: a synthesis of the results of TOROS project. Cont Shelf Res 21:1961-1973

Essink K (2003) Response of an estuarine ecosystem to reduced organic waste discharge. Aquat Ecol 37:65-76

González-Oreja JA, Saiz Salinas JI (2003) Recovery simulations of grossly polluted sediments in the Bilbao Estuary. Mar Pollut Bull 46:42-48

Govaere JCR, Van Damme D, Heip C, De Coninck LAP (1980) Benthic communities in the Southern Biight of the North Sea and their use in ecological monitoring. Helgol Wissenschaftliche Meeresunters 33:507-521

Hawkins SJ, Gibbs PE, Pope ND, Burt GR, Chesman BS, Bray S, Proud SV, Spence SK, Southward AJ, Langston WJ (2002) Recovery of polluted ecosystems: the case for long-term studies. Mar Environ Res 54:215-222

Herman PMJ, Heip C (1988) On the use of meiofauna in ecological monitoring: Who needs taxonomy? Mar Pollut Bull 19:665-668

Livingston RJ (1987) Field sampling in estuaries: the relationship of scale to variability. Estuaries 10:194-207

Luque CJ, Castellanos EM, Castillo JM, Gonzalez M, GonzalezVilches MC, Figueroa ME (1999) Metals in halophytes of a contaminated estuary (Odiel Saltmarshes, SW Spain). Mar Pollut Bull 38:49-51

Marques JC, Maranhao P, Pardal MA (1993) Human impact assessment on the subtidal macrobenthic community structure in the Mondego Estuary (Western Portugal). Est Coast Shelf Sci 37:403-419

Matthiessen P, Law RJ (2002) Contaminants and their effects on estuarine and coastal organisms in the United Kingdom in the late twentieth century. Environ Pollut 120:739-757

Morillo J, Usero J, Gracia I (2005) Biomonitoring of trace metals in a mine-polluted estuarine system (Spain). Chemosphere 58:14211430

Mucha AP, Vasconcelos MTSD, Bordalo AA (2003) Macrobenthic community in the Douro estuary: relations with trace metals and natural sediment characteristics. Environ Pollut 121:169-180

Mucha AP, Vasconcelos MTSD, Bordalo AA (2005) Spatial and seasonal variations of the macrobenthic community and metal contamination in the Douro estuary (Portugal). Mar Environ Res 60:531-550

Nelson CH, Lamothe PJ (1993) Heavy metal anomalies in the Tinto and Odiel River and estuary system, Spain. Estuaries 16:496-511

Nieva FJJ, Diaz-Espejo A, Castellanos EM, Figueroa ME (2001) Field variability of invading populations of Spartina densiflora Brong. in different habitats of the Odiel Marshes (SW Spain). Est Coast Shelf Sci 52:515-527

Pagola-Carte S, Urkiaga-Alberdi J, Bustamante M, Saiz-Salinas JI (2001) Concordance degrees in macrozoobenthic monitoring programmes using different sampling methods and taxonomic resolution levels. Mar Pollut Bull 44:63-70

Pearson TH, Rosenberg R (1978) Macrobenthic succession in relation to organic enrichment and pollution on the marine environment. Oceanogr Mar Biol Ann Rev 16:229-311

Peeters ETHN, Gardeniers JJP, Koelmans AA (2000) Contribution of trace metals in structuring in situ macroinvertebrate community composition along a salinity gradient. Environ Toxicol Chem 19:1002-1010

Rakocinski CF, Brown SS, Gaston GR, Heard RW, Walker WW, Summers JK (1997) Macrobenthic responses to natural and contaminant-related gradients in northern Gulf of Mexico estuaries. Ecol Appl 7:1278-1298

Ruiz F (2001) Trace metals in estuarine sediments from the Southwestern Spanish Coast. Mar Pollut Bull 42:482-490

Ruiz F, González-Regalado ML, Borrego J, Morales JA, Pendón JG, Muñoz JM (1998) Stratigraphic sequence, elemental concentrations and heavy metal pollution in Holocene sediments from the Tinto-Odiel Estuary, southwestern Spain. Environ Geol 34:270 278

Ruiz F, González-Regalado ML, Borrego J, Abad M, Pendón JG (2004) Ostracoda and foraminifera as short-term tracers of environmental changes in very polluted areas: the Odiel Estuary (SW Spain). Environ Pollut 129:49-61

Ruiz F, Borrego J, González-Regalado ML, López González N, Carro B, Abad M (2008) Impact of millennial mining activities on sediments and microfauna of the Tinto River estuary (SW Spain). Mar Pollut Bull 56:1258-1264

Sainz A, Ruiz F (2006) Influence of the very polluted inputs of the Tinto-Odiel system on the adjacent littoral sediments of southwestern Spain: A statistical approach. Chemosphere 62:1612-1622

Sáinz A, Grande JA, De la Torre ML (2003) Analysis of the impact of local corrective measures on the input of contaminants from the Odiel river to the Ría of Huelva (Spain). Water Air Soil Pollut 144:375-389

Saiz-Salinas JI, González-Oreja JA (2000) Stress in estuarine communities: Lessons from the highly-impacted Bilbao estuary (Spain). J Aquat Ecosyst Stress Recovery 7:43-55 
Sanchez MI, Green AJ, Castellanos EM (2006) Temporal and spatial variation of an aquatic invertebrate community subjected to avian predation at the Odiel salt pans (SW Spain). Arch Hydrobiol 166:199-223

Sánchez-Moyano JE, García-Adiego EM, García-Asencio I, GarcíaGómez JC (2003) Influencia del gradiente ambiental sobre la distribución de las comunidades macrobentónicas del estuario del río Guadiana. Bol Inst Esp Oceanogr 19:123-133

Sánchez-Moyano JE, Fa DA, Estacio FJ, García-Gómez JC (2006) Monitoring of marine benthic communities and taxonomic resolution: an approach through diverse habitats and substrates along the Southern Iberian coastline. Helgol Mar Res 60:243255

Sousa R, Dias S, Antunes JC (2006) Spatial subtidal macrobenthic distribution in relation to abiotic conditions in the Lima estuary, NW of Portugal. Hydrobiologia 559:135-148

Ter Braak CJF (1986) Canonical correspondence analysis: A new eigenvector technique for multivariate direct gradient analysis. Ecol 67:1167-1179

Ter Braak CJF (1990) Interpreting canonical correlation analysis through biplots of structure correlations and weights. Psychometrika 55:519-531

Thrush SF, Pridmore RD, Hewitt JE (1994) Impacts on soft-sediment macrofauna: the effects of spatial variation on temporal trends. Ecol Appl 4:31-41

Turner SJ, Thrush SF, Pridmore RD, Hewitt JE, Cummings VJ, Maskery M (1995) Are soft-sediment communities stable? An example from a windy harbour. Mar Ecol Prog Ser 120:219-230

Usero J, Morillo J, Gracia I, Leal A, Ollero C, Fraidías J, Fernández P (2000) Contaminación metálica y toxicidad en los sedimentos de los ríos Tinto y Odiel. Consejería de Medio Ambiente, Junta de Andalucía, Sevilla

Vanderklift MA, Ward TJ, Jacoby CA (1996) Effect of reducing taxonomic resolution on ordinations to detect pollution-induced gradients in macrobenthic infaunal assemblages. Mar Ecol Prog Ser 136:137-145

Warwick RM (2001) Evidence for the effects of metal contamination on the intertidal macrobenthic assemblages of the Fal estuary. Mar Pollut Bull 42:145-148

Warwick RM, Clarke KR (1991) A comparison of some methods for analysing changes in benthic community structure. J Mar Biol Ass UK 71:225-244

Warwick RM, Clarke KR (1993) Comparing the severity of disturbance: A meta-analysis of marine macrobenthic community data. Mar Ecol Prog Ser 92:221-231

Warwick RM, Goss-Custard JD, Kirby R, George CL, Pope ND, Rowden AA (1991) Static and dynamic environmental factors determining the community structure of estuarine macrobenthos in SW Britain: Why is the Severn estuary different? J Appl Ecol 28:329-345

Wolf WJ (1983) Estuarine benthos. In: Ketchum BH (ed) Ecosystems of the world. Estuaries and enclosed seas, vol 26. Elsevier, Amsterdam, pp 337-374

Ysebaert T, Herman PMJ (2002) Spatial and temporal variation in benthic macrofauna and relationships with environmental variables in an estuarine, intertidal soft-sediment environment. Mar Ecol Prog Ser 244:105-124

Ysebaert T, Meire P, Herman PMJ, Verbeek H (2002) Macrobenthic species response surfaces along estuarine gradients: prediction by logistic regression. Mar Ecol Prog Ser 225:79-95 